\title{
Investigating the effects of liquidity and exchange rate on Tehran Stock Exchange
}

\author{
Younos Vakil Alroaia, Khosro Faghani Makrani and Amir Banagozar*
}

Department of Management and Accounting, Semnan Branch, Islamic Azad University, Semnan, Iran

\begin{tabular}{|c|c|}
\hline$\overline{C H R O N I C L E}$ & A B S T RA C T \\
\hline $\begin{array}{l}\text { Article history: } \\
\text { Received January } 28,2014 \\
\text { Accepted } 20 \text { June } 2014 \\
\text { Available online } \\
\text { June } 262014 \\
\text { Keywords: } \\
\text { Tehran Stock Exchange } \\
\text { Liquidity } \\
\text { Exchange rate }\end{array}$ & $\begin{array}{l}\text { This paper presents an empirical investigation to study the effects of two macroeconomic } \\
\text { factors; namely exchange rate and liquidity on stock index. The proposed study was applied in } \\
\text { Iran and on major index of Tehran Stock Exchange over the period 2001-2011. They reported } \\
\text { that the currency exchange maintained negative impact on stock exchange for the period of } \\
\text { investigation. This is due to the fact that when currency devalued, working capital decreases } \\
\text { and firms did not enough money to purchase raw materials, pay wages, etc. In addition, } \\
\text { liquidity marinated a direct and positive relationship with exchange index. However, the impact } \\
\text { of liquidity seems to be bigger than currency exchange. }\end{array}$ \\
\hline
\end{tabular}

(C) 2014 Growing Science Ltd. All rights reserved.

\section{Introduction}

For years, there were major concern to learn how some macroeconomic factors could influence on stock exchange. Bartram and Bodnar (2012), for instance, investigated the conditional relation between exchange rate exposure and stock returns in emerging and developed markets. They argued that the impact of exchange rate exposure on stock returns was conditional and presented some evidence of a substantial return effect to firm-level currency exposures when conditioning on the exchange rate change. They also explained that the realized return to exposure was directly associated with the size and sign of the exchange rate change, implying fluctuations in exchange rates as a source of time-variation in currency return premia. They reported that foreign exchange rate exposure estimates were economically meaningful, in spite the fact that individual time-series results were noisy and various exposures were not statistically substantial, and that exchange rate exposure played an important role in generating cross-sectional return variation. Finally, they explained that the relationship between exchange rate exposure and stock returns was more consistent with a cash flow impact than a discount rate.

*Corresponding author.

E-mail addresses: amir.banagozar@yahoo.com (A. Banagozar) 
Mahmood et al. (2007) investigated the dynamics relationship between stock prices and economic variables in six Asian-Pacific selected countries of Malaysia, Korea, Thailand, Hong Kong, Japan, and Australia. They applied the monthly data on stock price indices, foreign exchange rates, consumer price index and industrial production index that spans over the period 1993-2002. Their results indicated the existing of a long run equilibrium relationship between and among variables in only four countries, i.e., Japan, Korea, Hong Kong and Australia. As for short run relationship, all countries except for Hong Kong and Thailand indicated some interactions. The Hong Kong represented relationship only between exchange rate and stock price while the Thailand showed substantial interaction only between output and stock prices. A precise estimation of the relationship between the economic variables and stock market behavior helped the investors, both local and foreign, make effective investment decisions. At the same time, for the policy makers, a precise prediction of this kind of relationship helps government agencies in designing policies to encourage more capital inflows into the respective countries' capital market.

Nydahl (1999) investigated the impact of exchange rate fluctuation on a firm's value, the so-called exchange rate exposure, for a sample of Swedish firms. In contrast to previous findings, using U.S. data, the values of Swedish firms, as reflected in the stock price, appeared quite sensitive to movements in the exchange rate. Studying the cross sectional differences in exposure, the estimated exposure was positively and substantially associated with the fractional of total sales made abroad and negatively associated with the use of currency derivatives.

Pan et al. (2007) investigated dynamic linkages between exchange rates and stock prices for several East Asian countries, including Hong Kong, Japan, Korea, Malaysia, Singapore, Taiwan, and Thailand. They reported a significant causal relationship from exchange rates to stock prices for Hong Kong, Japan, Malaysia, and Thailand before the 1997 Asian financial crisis. They also reported a causal relationship from the equity market to the foreign exchange market for Hong Kong, Korea, and Singapore. In addition, while no country indicated a substantial causality from stock prices to exchange rates during the Asian crisis, they reported a causal relationship from exchange rates to stock prices for all countries except Malaysia. Their results were robust with in terms of different testing techniques applied. The results also indicated that the linkages vary across economies with in terms of exchange rate regimes, the trade size, the degree of capital control, and the size of equity market.

Pastor and Stambaugh (2001) investigated whether market-wide liquidity was a state variable important for asset pricing. They reported that expected stock returns were associated with the sensitivities of returns to fluctuations in aggregate liquidity. Salehi and Biglar (2009) tried to find out whether or not the capital-structure decision influences on firms' performance. They used 3 definitions of capital structure in scope of book value to market value and 5 measures for financial performance. They reported that capital structure could influence financial performance. The significance of the influence of capital structure on performance respectively was associated with measures of adjusted value, market value and book value.

Salehi et al. (2011) studied the relationship between stock returns and its liquidity ability in firms listed on Tehran Stock Exchange over the period 2002-2009. They reported that there was a negative correlation between stock returns with its liquidity. Zhao (2010) analyzed the dynamic relationship between Renminbi (RMB) real effective exchange rate and stock price with VAR and multivariate generalized autoregressive conditional heteroskedasticity $(\mathrm{GARCH})$ models. The results indicated that there was not any stable long-term equilibrium relationship between RMB real effective exchange rate and stock price. The study also examined the cross-volatility relationships between foreign exchange and stock markets using likelihood ratio statistic. They reported a bi-direction volatility spillovers effects between the two markets, implying the past innovations in stock market had an impact on future volatility in foreign exchange market, and vice versa. 


\section{The proposed study}

This paper presents an empirical investigation to study the effects of two macroeconomic factors; namely exchange rate and liquidity on stock index. The proposed study has been applied in Iran and on major index of Tehran Stock Exchange over the period 2001-2011. Table 1 shows some basic statistics on some three major variables.

Table 1

The summary of some basic statistics

\begin{tabular}{|c|c|c|c|}
\hline Variable & Stock Exchange & Liquidity & Exchange \\
\hline Symbol & TE & $\mathrm{M}$ & EXG \\
\hline Mean & 11495 & 1361650.39 & 9580 \\
\hline Median & 10227 & 1098681.95 & 9226 \\
\hline Max & 26962 & 3522204.1 & 19148 \\
\hline Min & 3348 & 262789 & 7994 \\
\hline Standard deviation & 6051 & 966035.76 & 1993 \\
\hline Skewness & 1.096 & 0.66 & 3.14 \\
\hline Kurtosis & 3.78 & 2.24 & 14.5 \\
\hline
\end{tabular}

Based on the results of Table 1, there seems that all data were normally distributed. We first look at the relationship between stock exchange with each independent variables, exchange rate and liquidity. Table 2 shows the result of the effect of exchange rate on stock exchange.

Table 2

The summary of the effects of exchange rate on stock exchange

\begin{tabular}{cccc} 
& $\mathrm{t}$-value & $\mathrm{df}$ & Prob \\
\hline Exchange rate & 13.97087 & 4 & 0.0078 \\
\hline
\end{tabular}

As we can observe from the result of Table 2, t-value is statistically significant and we may confirm the effect of exchange rate on stock exchange. We need to also investigate whether there is any autocorrelation between residuals or not and Table 3 demonstrates the summary of our findings.

Table 3

The summary of testing autocorrelation effect

\begin{tabular}{ccc}
\hline Lags & LM-Stat & Prob \\
\hline 1 & 11.37416 & 0.7858 \\
2 & 14.90327 & 0.5317 \\
3 & 26.53560 & 0.0469 \\
4 & 19.62244 & 0.2377 \\
5 & 15.81224 & 0.4661 \\
6 & 17.06878 & 0.3812 \\
7 & 28.73844 & 0.0258 \\
8 & 25.74984 & 0.0577 \\
9 & 9.956095 & 0.8689 \\
10 & 39.26712 & 0.0010 \\
12 & 28.71015 & 0.0260 \\
\hline
\end{tabular}

Based on the results of Table 3, we may conclude that there was not any auto-correlation among residuals. In addition, Chi-Square test for these two variables is equal to Chi-Square $=317.6839$ with Prob. $=0.5261$ and it indicates there was homogeneity of variance. Finally, we need to make sure that all residuals are normally distributed, which is accomplished by Jarqe-Bura test summarized in Table 4 as follows, 
Table 4

The summary of Jarqe-Bura test

\begin{tabular}{cccc}
\hline Component & Jarque-Bera & Df & Prob \\
\hline 1 & 0.181155 & 2 & 0.9134 \\
2 & 0.569363 & 2 & 0.7523 \\
3 & 6.019354 & 2 & 0.0493 \\
4 & 1.717499 & 2 & 0.4237 \\
\hline Common & 8.487371 & 8 & 0.3874 \\
\hline
\end{tabular}

As we can observe from the results of Table 4, all data are normally distributed. Similarly, we may look at relationship between liquidity and stock exchange in Table 5 as follows,

Table 5

The summary of relationship between liquidity and stock exchange

$\begin{array}{cccc} & \mathrm{T} & \mathrm{Df} & \text { Prob } \\ \text { Liquidity } & 23.10956 & 4 & 0.0001\end{array}$

The results of Table 5 also show that there was a meaningful relationship between liquidity and stock exchange. We need to also find out whether there is any auto-correlation between residuals or not and Table 6 shows the summary of our findings.

Table 6

The summary of testing autocorrelation effect

\begin{tabular}{ccc}
\hline Lags & LM-Stat & Prob \\
\hline 1 & 11.37416 & 0.7858 \\
2 & 14.90327 & 0.5317 \\
3 & 26.53560 & 0.0469 \\
4 & 19.62244 & 0.2377 \\
5 & 15.81224 & 0.4661 \\
6 & 17.06878 & 0.3812 \\
7 & 28.73844 & 0.0258 \\
8 & 25.74984 & 0.0577 \\
9 & 9.956095 & 0.8689 \\
10 & 39.26712 & 0.0010 \\
11 & 28.71015 & 0.0260 \\
\hline
\end{tabular}

According to the results of Table 6, we may conclude that there was not any auto-correlation among residuals. In addition, Chi-Square test for these two variables is equal to Chi-Square $=317.6839$ with Prob. $=0.5261$ and it indicates there was homogeneity of variance. Finally, we need to make sure that all residuals are normally distributed, which is accomplished by Jarqe-Bura test summarized in Table 7 as follows,

Table 7

The summary of Jarqe-Bura test

\begin{tabular}{cccc}
\hline Component & Jarque-Bera & Df & Prob \\
\hline 1 & 0.181155 & 2 & 0.9134 \\
2 & 0.569363 & 2 & 0.7523 \\
3 & 6.019354 & 2 & 0.0493 \\
4 & 1.717499 & 2 & 0.4237 \\
\hline Common & 8.487371 & 8 & 0.3874 \\
\hline
\end{tabular}

The results of Table 7 also indicate that all data were normally distributed. The proposed model of this paper considers the following regression model, 
$T E=\beta_{0}+\beta_{1} T E_{t-1}+\beta_{2} T E_{t-2}+\beta_{3} T E_{t-3}+\beta_{4} T E_{t-4}+\beta_{5} M_{t-1}+\beta_{6} M_{t-2}+\beta_{7} M_{t-3}+\beta_{8} M_{t-4}+\beta_{9} E X G_{t-1}$

$+\beta_{10} E X G_{t-2}+\beta_{11} E X G_{t-3}+\beta_{12} E X G_{t-4}+\varepsilon$

where $T E$ represents Tehran Exchange index, $E X G$ states exchange rate and $M$ represents liquidity. In addition, $\beta_{\mathrm{i}}$ and $t$ represent the coefficients, which must be estimated.

\section{The results}

In this section, we present details of our findings on the implementation of regression analyses.

$T E=0.616349392646 \times T E(-1)+0.627023100139 \times T E(-2)-0.144812837275 \times T E(-3)+0.00278969717182 \times T E(-4)+$ $0.0176461318698 \times M(-1)+0.007126126042 \times M(-2)-0.0173787434596 \times M(-3)-0.00181292477214 \times M(-4)+$ $0.0141827820184 \times E X G(-1) \quad-\quad 1.60938320918 \times E X G(-2) \quad-\quad 0.382187943218 \times E X G(-3) \quad-\quad 5.6732345234 \times E X G(-4) \quad+$ 57705.8070007

Table 8 summarizes details of our results on Chi-Square test for various variables.

\section{Table 8}

The summary of Chi-Square test

\begin{tabular}{cccc}
\hline Dependent variable: TE & & & \\
\hline Excluded & Chi-sq & df & Prob. \\
\hline M & 23.10956 & 4 & 0.0001 \\
EXG & 13.97087 & 4 & 0.0074 \\
All & 69.12143 & 12 & 0.0000 \\
\hline Dependent variable: M & Chi-sq & df & Prob. \\
\hline Excluded & 8.133553 & 4 & 0.0868 \\
\hline TE & 8.274531 & 4 & 0.0120 \\
EXG & 25.65884 & 12 & 0.0120 \\
\hline Dependent variable: EXG & & & \\
\hline Excluded & Chi-sq & df & Prob. \\
\hline TE & 1.718556 & 4 & 0.7873 \\
All & 6.407537 & 4 & 0.6707 \\
\hline
\end{tabular}

\section{Discussion and results}

Based on the results of Eq. (2), we may realize that the currency exchange maintained negative impact on stock exchange for the period of investigation. This is due to the fact that when currency devalued, working capital decreases and firms did not enough money to purchase raw materials, pay wages, etc. In addition, liquidity marinated a direct and positive relationship with exchange index. However, the impact of liquidity seems to be bigger than currency exchange. Note that during the years of 2011 to 2012, exchange rate was devalued, significantly and on the contrary, of the results of this study, stock exchange jumped up substantially. The results could be described because many petrochemical firms had the opportunity to purchase the raw materials from the government at low price and sell their product in higher price.

\section{Acknowledgement}

The authors would like to thank the anonymous referees for constructive comments on earlier version of this paper.

\section{References}

Bartram, S. M., \& Bodnar, G. M. (2012). Crossing the lines: The conditional relation between exchange rate exposure and stock returns in emerging and developed markets. Journal of International Money and Finance, 31(4), 766-792. 
Mahmood, W., Mansor, W., \& Mohd Dinniah, N. (2007). Stock returns and macroeconomic influences: Evidence from the six Asian-Pacific countries. Financial Economics and Futures Market Research Paper.

Nydahl, S. (1999). Exchange rate exposure, foreign involvement and currency hedging of firms: some Swedish evidence. European Financial Management,5(2), 241-257.

Pan, M. S., Fok, R. C. W., \& Liu, Y. A. (2007). Dynamic linkages between exchange rates and stock prices: Evidence from East Asian markets. International Review of Economics \& Finance, 16(4), 503-520.

Pastor, L., \& Stambaugh, R. F. (2001). Liquidity risk and expected stock returns (No. w8462). National Bureau of Economic Research, 642-685.

Salehi, M., \& Biglar, K. (2009). Study of the relationship between capital structure measures and performance: evidence from Iran. International Journal of Business and Management, 4(1), 97.

Salehi, M., Talebnia, G., \& Ghorbani, B. (2011). A study of the relationship between liquidity and stock returns of companies listed in Tehran Stock Exchange. World Applied Sciences Journal, 12(9), 1403-1408.

Zhao, H. (2010). Dynamic relationship between exchange rate and stock price: Evidence from China. Research in International Business and Finance, 24(2), 103-112. 